\title{
軟らかい砂質土を走行する車輪の解析 \\ （相互作用による砂質土の流動について）
}

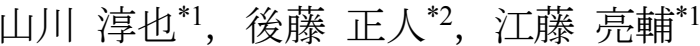

\section{Analysis of traveling wheel on loose sandy soil (Sandy soil flow beneath a wheel due to the interaction)}

\author{
Junya YAMAKAWA*1, Masato GOTO*2 and Ryosuke ETO*1 \\ ${ }^{* 1}$ Department of Mechanical Engineering, The National Defense Academy \\ 1-10-20 Hashirimizu, Yokosuka-shi, Kanagawa 239-8686, Japan \\ ${ }^{* 2}$ Graduate School of Science and Engineering, The National Defense Academy \\ 1-10-20 Hashirimizu, Yokosuka-shi, Kanagawa 239-8686, Japan
}

Received: 26 April 2017; Revised: 4 June 2017; Accepted: 11 July 2017

\begin{abstract}
Soil-vehicle interaction is an important factor for predicting trafficability of off-road vehicles. Tractive forces on the wheel to drive the vehicle can be estimated by soil deformation analysis around the contact area of the wheel. Sand deformation and flow under a rolling wheel with slippage were observed from the side through a transparent acrylic wall by 2-dimensional Particle Image Velocimetry (PIV) method. The flow velocities of sand particles obtained on allocated grids revealed that periodic fluctuations of sand flow make ripple patterns on the sand surface behind the wheel. We discussed the effect of wheel slip ratios on the density of the ripples, sinkage, drawbar pull, torque and the depth of influence for the traveling wheel. The result showed that the slipping wheel forms a ripple with each scratch by the wheel rotation corresponding to the front half contact length with sand. The thickness of sand flow layer under the wheel showed thinner for large slip ratios. The finite element method was also conducted to simulate the traveling wheel experiment to discuss the possibility of the numerical simulation. The result of simulation qualitatively reproduced the experiment. However, there was a quantitative difference on the drawbar pull of the wheel, which shows that the method needs modification on the numerical model.
\end{abstract}

Key words : Sand flow, PIV, Rigid wheel, Tractive force, Numerical simulation, Finite element method

\section{1. 緒言}

機械と地面の相互作用に関する研究はテラメカニックス(Muro and O'Brien, 2004)と呼ばれ，農業機械，建設機 械，宇宙開発といった様々な分野で必要とされる．近年各国で惑星探査が行われており，ローバによる地質調査 やサンプル収集などが進められている(Chhaniyara et al., 2012). 日本でも月着陸実証機の開発に着手しており (JAXA, 2016)，民間レベルで月面ローバの開発(HAKUTO, 2017)が進むなど，今後の月面探査への発展が期待され ている，一方で地上に目を向ければ，全国には土砂災害危険箇所が多数存在し(内閣府, 2016), 災害発生時には人 命救助や復旧作業で迅速な活動が求められる．特殊な環境において使用される車両は舖装された堅固な路面だけ でなく，砂や土のような軟らかい地面においても十分な走行性や作業性を確保しなければならない。

軟らかい地面における車両の走行では，輪荷重に対する十分な支持力と走行抵抗に対する十分な推進力を発生 させることが必要である。これらの支持力，推進力，走行抵抗の発生は地面と車輪の接触の相互作用によって生 じるために，その発生の仕組みを明らかにすることは重要であり，これまでに多くの研究者が車輪の沈下や牽引 力に着目した研究を行なっている(Wong, 1984, Tiwari et al., 2010). 摩擦性が大きい砂質土では車輪走行において牽 引力の発生は一様でなく変動がみられるが，それを詳細に検討した例はほとんどない，車輪下の土砂の動きを観

No.17-00188 [DOI: 10.1299/transjsme.17-00188], J-STAGE Advance Publication date : 26 July, 2017

*1 正員, 防衛大学校 機械工学科（干239-8686 神奈川県横須賀市走水 1-10-20）

*2 防衛大学校 理工学研究科

E-mail of corresponding author: yamakawa@nda.ac.jp 
察した研究(Shikanai et al., 2000, Senatore et al., 2013)では, 土砂粒子の動きからすべり線の発生に言及しているもの の，力の変動のしくみを十分に説明しておらず，車輪通過後の波状痕についても簡単に触れているだけである. 波状痕の発生については，沈下とすべり率が比較的小さい条件において数值解析で検討を行った例がわずかにあ るのみである(Ozaki et al., 2015). 軟らかい地面における車輪の走行モデルは様々に提案(Taheri et al., 2015)がなさ れているが，車輪と地面の相互作用は実験と数值解析を合わせて詳細な解明が可能となり，その結果は走行性予 測を行うための数值解析の精度向上に活かされる. 土砂の力学的性質はもとより車輪と土砂の組合せによりその 走行の性質は異なるために, 走行実験による多くのデータ収集とともに数值解析と合わせた検証が必要である.

本研究では，走行が困難となる軟らかい地面と車輪の相互作用における走行のしくみを十分に検討することを 目的に, 砂質土上での剛性車輪の走行実験を行った. 走行のしくみを解明する上で相互作用による地面の変形・ 流動に注目し, 走行状態で側面からの映像を撮り, 粒子画像速度測定法(PIV)で車輪下の砂の流動を可視化した. 走行時の車輪に発生する牽引力, 車輪の沈下量, 通過後に車輪後方の砂面に生じる波数等と車輪すべり率の関係 から走行における特性を明らかにした。 また, 有限要素法により実験の再現を行い, 数值解析を用いた車輪走行 予測の可能性を検討した.

\section{2. 車輪走行実験による砂の流動解析}

\section{$2 \cdot 1$ 車輪走行実験}

図 1 に車輪走行実験に用いた装置を示す.アクリル板で側面を観察できる幅 $100 \mathrm{~mm}$, 長さ $1050 \mathrm{~mm}$, 深さ 180 $\mathrm{mm}$ の容器に密度 $\rho=2.63 \times 10^{3} \mathrm{~kg} / \mathrm{m}^{3}$, 粒径 $0.2 \mathrm{~mm}$ 程度でほぼ均一な豊浦砂(細野, 吉嶺, 2009)を入れて水平にな らした表面において半径 $94 \mathrm{~mm}$, 幅 $98 \mathrm{~mm}$ のアルミニウム車輪による走行実験を行なった. 車輪踏面は摩擦を増 すためにゴム系の滑り止めを塗布している，車輪とモータはともにスライダで上下に自由に動くものの，前後方 向には固定されて砂槽が前後に動く構造となっているため, 任意のすべり率において固定したカメラで車輪を中 心にして砂の動きを観察できる．車輪と砂槽はそれぞれ速度の設定が可能なモータで駆動する．砂は緩いままで 締め固めず, 自重で安定した自然な状態とした。すべり率 $s$ は次式で定義した.

$$
s=\frac{v_{r}-v_{t}}{v_{r}}
$$

ここで， $v_{r}$ は車輪踏面の周速度， $v_{t}$ は車輪（砂槽）の移動速度である.

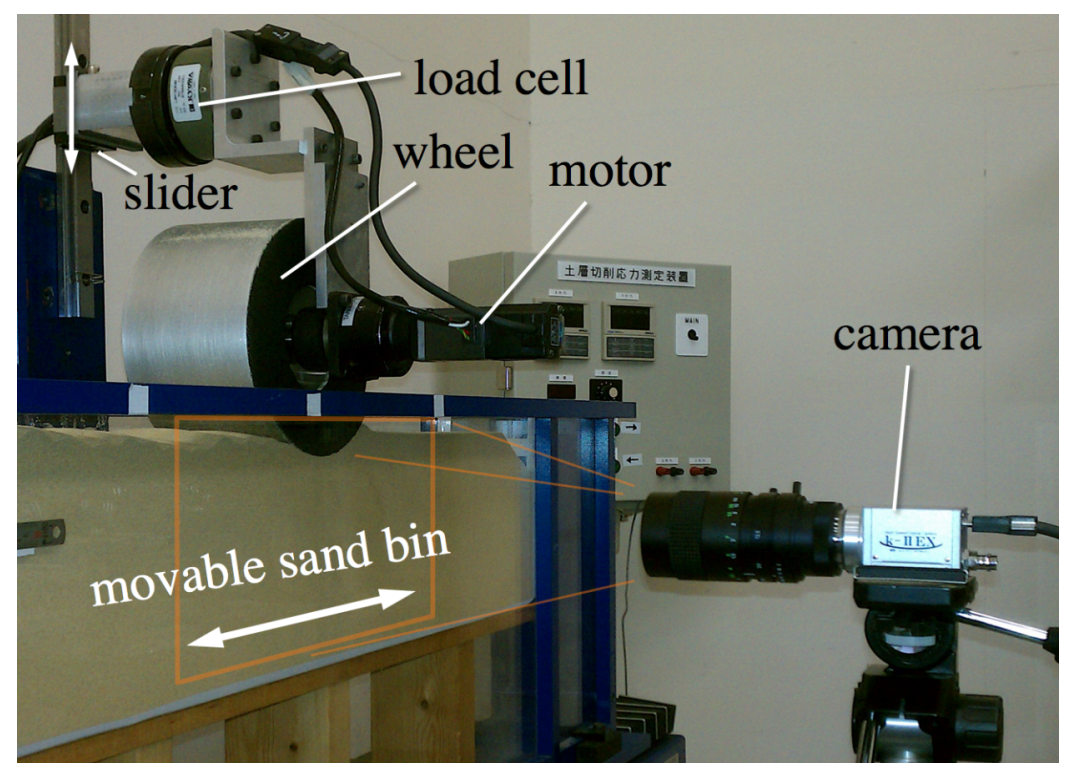

Fig. 1 Sand-wheel interaction observation system. 
輪荷重の影響を見るために, 車輪と駆動モータ等の自重 $80 \mathrm{~N}$ を基準として, 重りを載せるかワイヤで引き上げ ることで輪荷重の増減が可能な装置となっている. 走行中のすべり率は一定であり, 車輪周速度ならびに移動速 度は実験開始直後と停止直前を除いて一定とした. 実験装置の構造上, 側方への砂の流動がないため, 輪荷重を 掛けると側方（壁）より圧力を受ける. 実験では近似的な平面歪み(Timoshenko and Goodier, 1987)の状態を再現し ており，車輪下の砂の流動について二次元的な運動を観察することとなる．また，車輪上部のロードセルは車輪 前後方向に作用する力を計測する．これは車輪が発生する推進力から走行抵抗を引いた車輪を前進させる正味の 力である牽引力となる. また, 車輪が発生するトルクは専用の器具を取付けて駆動モータの反力から測定する.

\section{$2 \cdot 2$ 車輪走行における砂の流動}

カメラで撮影した走行の様子は PIV で解析する. 2 時刻の画像間における砂粒子の位置の差から, 砂の流動速 度を算出する. 車輪周速度 $V_{r}=50 \mathrm{~mm} / \mathrm{s}$, 寸べり率 $20 \%$ と $50 \%$ における PIV 解析の結果を図 2 に示す. 砂との接 触部分を拡大して示しており，車輪は右に回転，す心゙りを伴いながら右方向へ（実際は砂槽が左一）移動してい る. 図中の矢印は砂粒子の速度べクトルを表しており，青色から赤色へと速くなる．車輪下の流動は一様ではな く, 砂が下方一比較的小さく変位する状態と砂が後方に大きく流動する状態が交互に現れるが，それぞれの画像 を上下に示した，それぞれのすべり率で同様であるが，上図では車輪の移動にともない車輪後方には嘾に相当す る間隙ができる．これが次第に後方へ広がると車輪による砂面への拘束力が低下し，下図のように後方への大き な砂の流動に発展寸ると考えられる．図３は砂面を横から見たものであるが，車輪通過後に波が形成されている ことが分かる. これは前に述べた砂の動きの変化と関連しており, 砂が大きく流動するときに車輪後方に砂の山 ができるためである.

図 4 は同じく車輪走行後の砂面を各すべり率において上から見たものである.すべり率が $20 \%$ 以上で波状の車 輪通過痕が発生しているが，すべり率 10\%以下では観察できない. また，すべり率が大きくなるにつれて，波形 の間隔は密になることが分かる. 車輪の移動速度はすべり率で異なるが，車輪周速度 $50 \mathrm{~mm} / \mathrm{s}$ ではすべり率によ らずほぼ $1 \mathrm{~s}$ 毎に波形が一つできており，車輪移動速度により波形の間隔が変わる. 図 5 は砂の流れの大まかな イメージである．もともと車輪下にあった砂（赤で表示）が後方へ移動する（すぐ後方の青で表示）ことによっ て車輪通過後に波形が生じることが説明できる. 表 1 は車輪周速度と移動速度ならびに波数等を示している. 山 ができる 1 周期に車輪踏面が周方向に動く距離を計算したのが最右列である．すべり率，移動速度によらず，一 つの山ができるたびに車輪の踏面は周方向に 45-70 mm 動いていることになる. この長さは図 6 に示寸車輪と砂 が接触する踏面前面の長さにほぼ相当するため (沈下量によって変わるものの), 車輪が踏面前方の長さ分の砂を 掻くたびに砂を大きく後方一流動させていると解釈できる.

\section{$2 \cdot 3$ 車輪の沈下と砂の流動厚さ}

軟らかい地面を走行する時に車輪は沈下により抵抗が増加して走行に支障をきたすが，ここでは車輪の沈下と 走行によって影響を受ける砂の深さについて考察を行った．車輪沈下量を走行前の砂表面から車輪最下端までの 距離として, また, 流動厚さを車輪最下端から砂が流動する境界までの距離として定義する (図 7). また, 沈下 量に流動厚さを加えて影響深さとした. PIV では $3 \mathrm{~mm}$ 間隔で二次元上に配置した点上で粒子の速度を得るが, 速度が大きく異なる 2 点間に境界があるとした. 図 8 の実線は, 車輪周速度 $V_{r}=50 \mathrm{~mm} / \mathrm{s}$ において, 車輪の沈下 量ならびに流動厚さをすべり率との関係で示したものである. 車輪の沈下はすべり率とともに増加するが, 砂の 流動厚さは逆に減少する傾向にある。沈下量に流動厚さを加えた影響深さをムで示しているが，車輪周速度が一 定の条件では, 影響深さはす心゙り率に関わらずほぼ一定 $(30 \mathrm{~mm})$ を示している. 車輪回転速度が変わらなければ, 走行時の車輪が影響を及ぼす砂の深さはすべり率によらないことになり，ある一定の深さまでを相互作用の解析 範囲とすれば良いと言える. 先に示した条件では車輪半径の約 $1 / 3$ となる. 一方, 移動速度 $V_{t}=20 \mathrm{~mm} / \mathrm{s}$ を一定 にしてすべり率を変化させたときのそれぞれの值を図中に破線で示している．このとき，すべり率とともに周速 度は増加しているが, 影響深さ（ $\triangle$ で表示）も増加する傾向にある. 


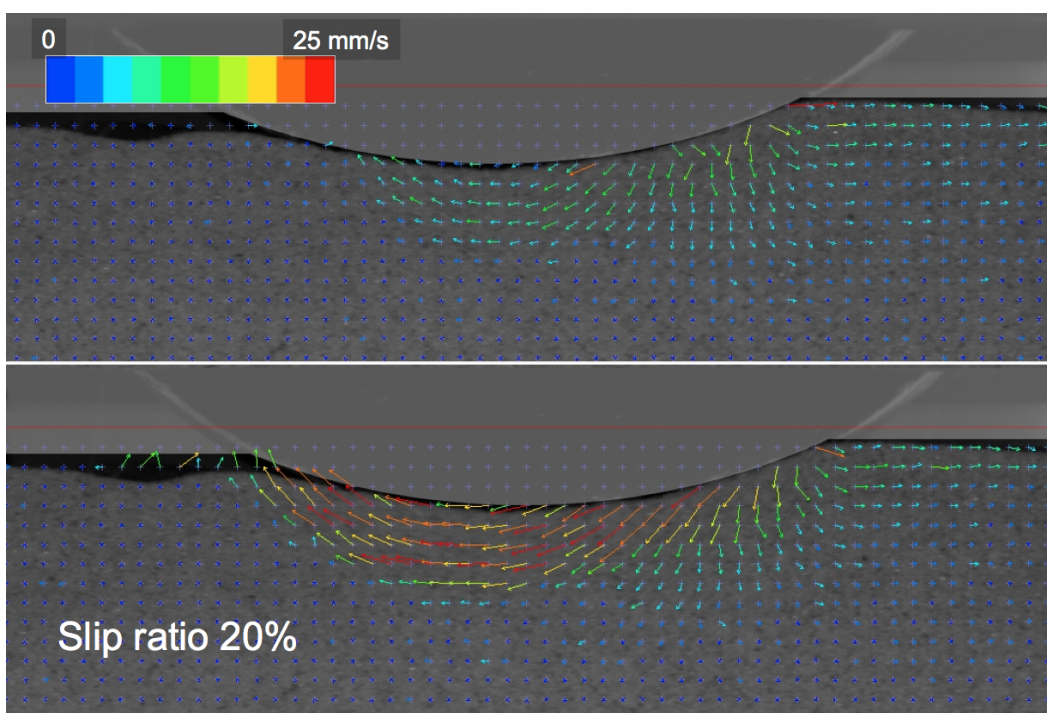

(a) slip ratio $20 \%$

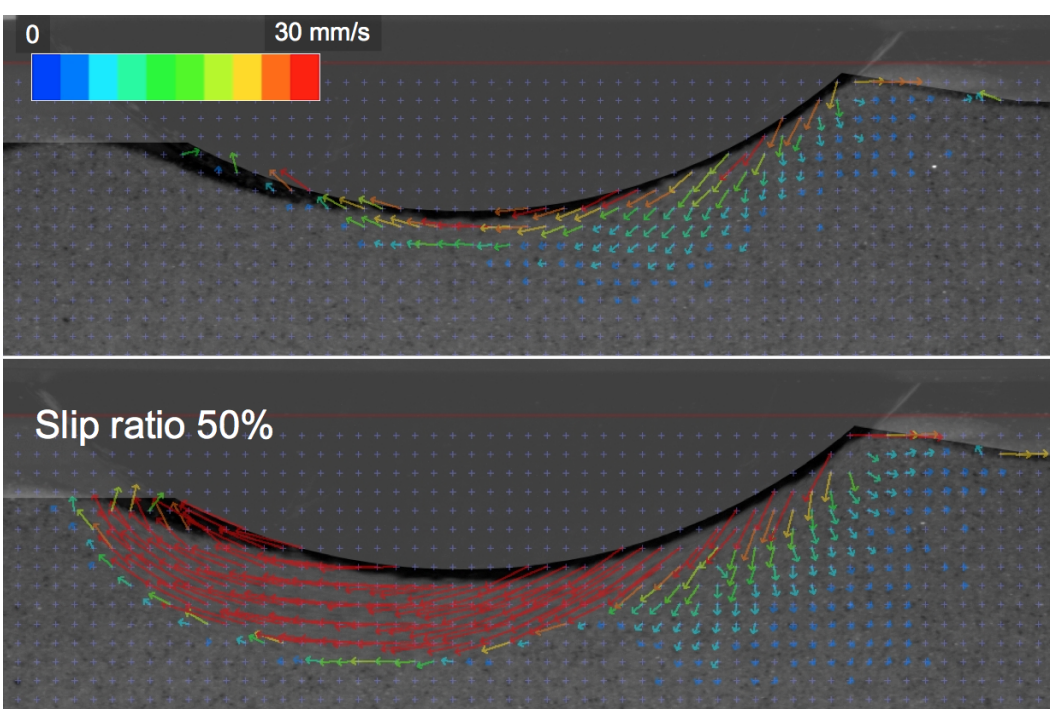

(b) slip ratio $50 \%$

Fig. 2 Two patterns of sand motion beneath the wheel at slip ratios of (a) $20 \%$ and (b) $50 \%\left(V_{r}=50 \mathrm{~mm} / \mathrm{s}\right)$. Each top: sand movement is small; each bottom: sand flow is large.

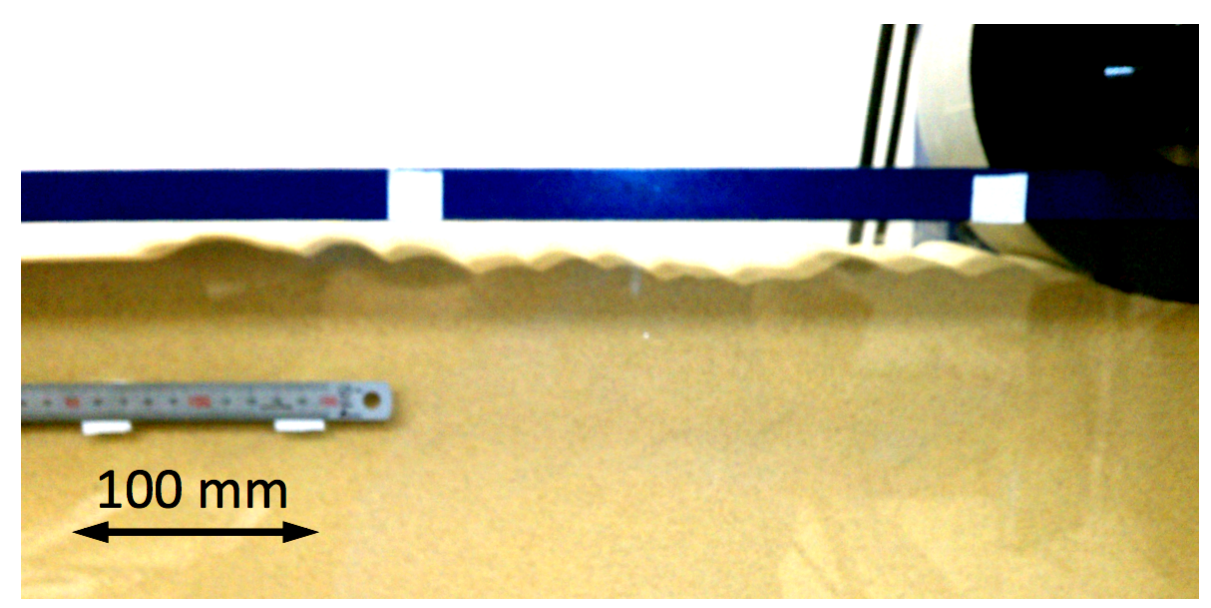

Fig. 3 The wheel makes ripples behind on the sand surface after passing over. 


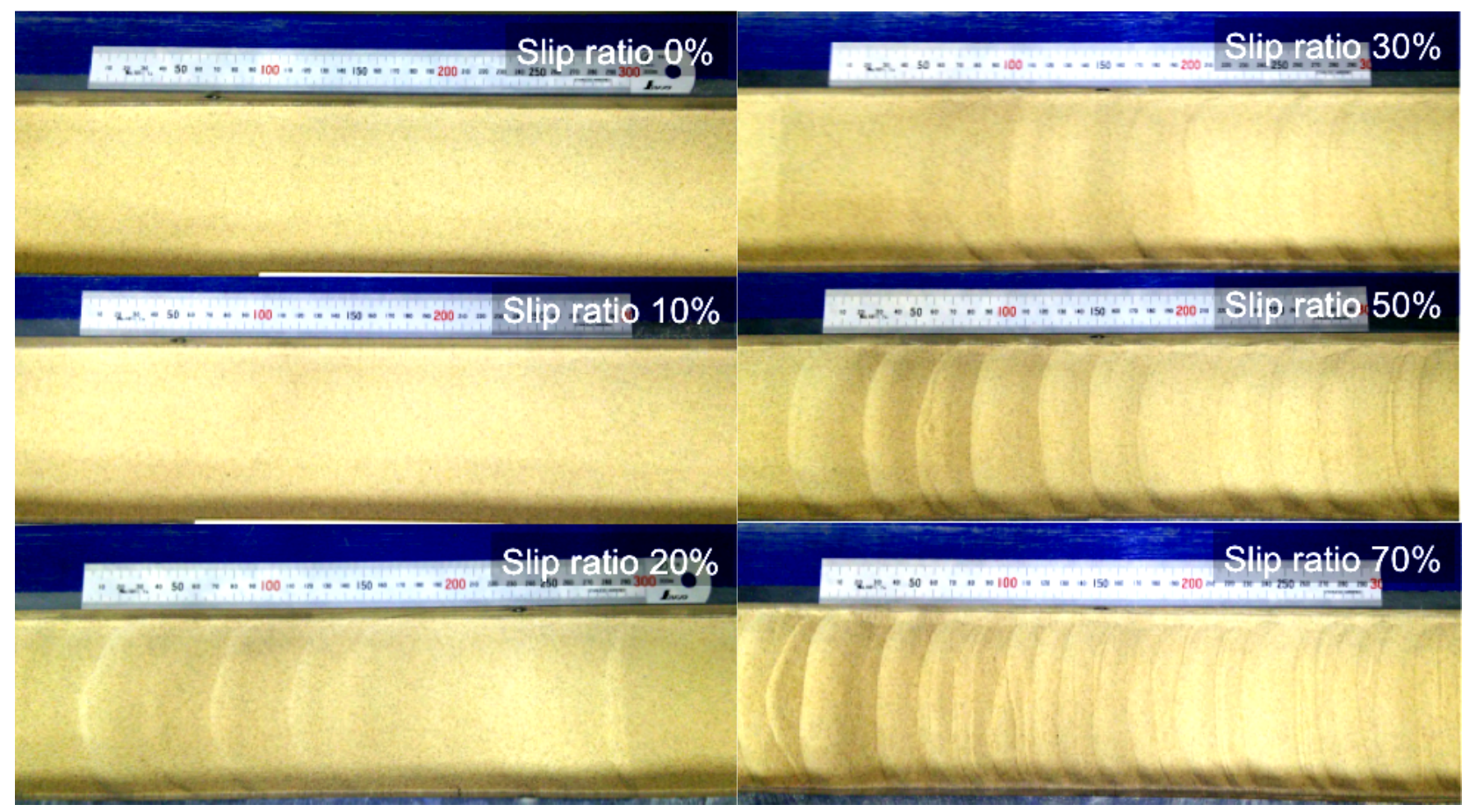

Fig. 4 Ripples behind the wheel for various slip ratios from 0 to $70 \%$.

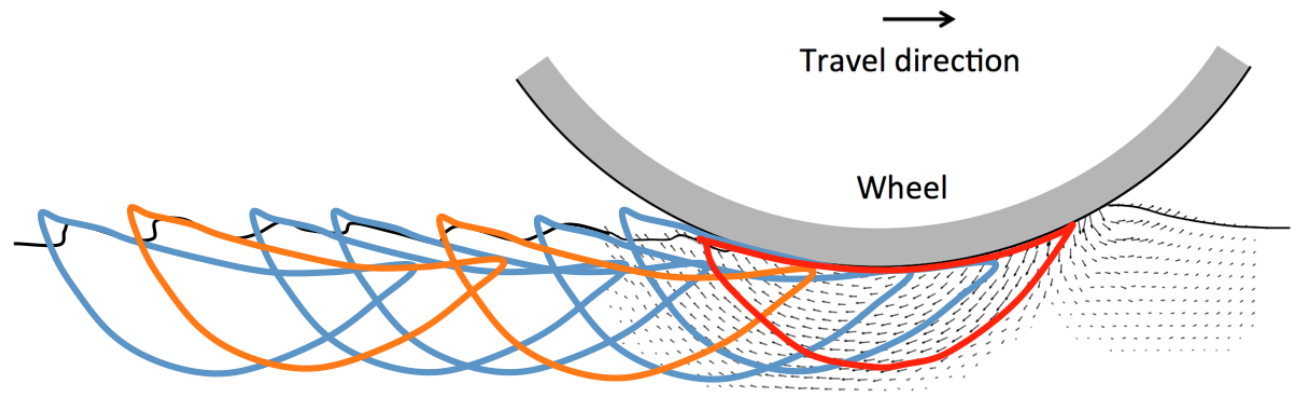

Fig. 5 Simple illustration for generating ripples behind the rolling wheel with slippage.

Table 1 Wheel running condition and the time period to make a single hump.

\begin{tabular}{|c|c|c|c|c|c|}
\hline $\begin{array}{c}\text { Wheel peripheral } \\
\text { velocity }[\mathrm{mm} / \mathrm{s}]\end{array}$ & $\begin{array}{c}\text { Slip ratio } \\
{[\%]}\end{array}$ & $\begin{array}{c}\text { Travel velocity } \\
{[\mathrm{mm} / \mathrm{s}]}\end{array}$ & $\begin{array}{c}\text { Number of } \\
\text { humps/200 mm }\end{array}$ & $\begin{array}{c}\text { Period } \\
{[\mathrm{s}]}\end{array}$ & $\begin{array}{c}\text { Moving circumferential } \\
\text { length per period [mm] }\end{array}$ \\
\hline 50 & 10 & 45 & - & - & - \\
\hline 50 & 20 & 40 & 5 & 1.00 & 50 \\
\hline 50 & 30 & 35 & 6 & 0.95 & 47.6 \\
\hline 50 & 50 & 25 & 8 & 1.00 & 50 \\
\hline 50 & 70 & 15 & 13 & 1.03 & 51.3 \\
\hline 25 & 20 & 20 & 4 & 2.50 & 62.5 \\
\hline 40 & 50 & 20 & 9 & 1.11 & 44.4 \\
\hline 67 & 70 & 20 & 10 & 1.00 & 66.7 \\
\hline
\end{tabular}




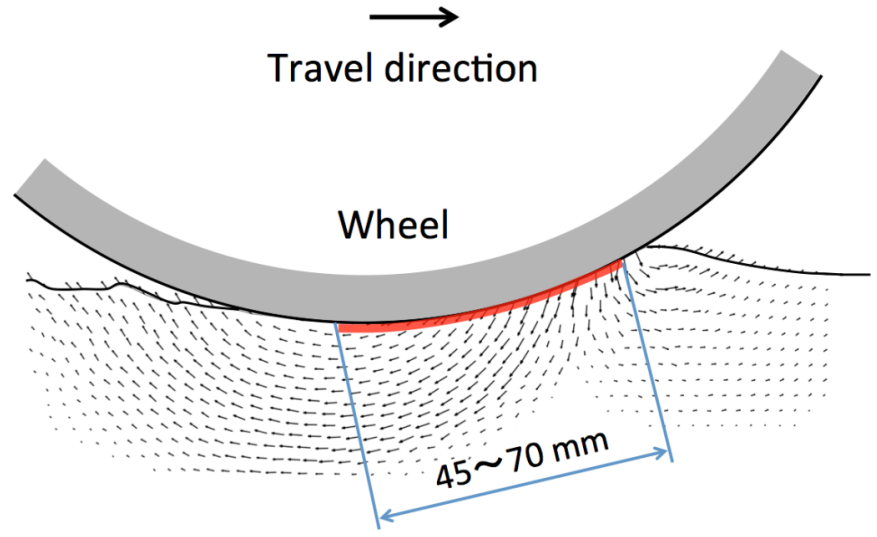

Fig. 6 Contact length with sand on the front half of the wheel.

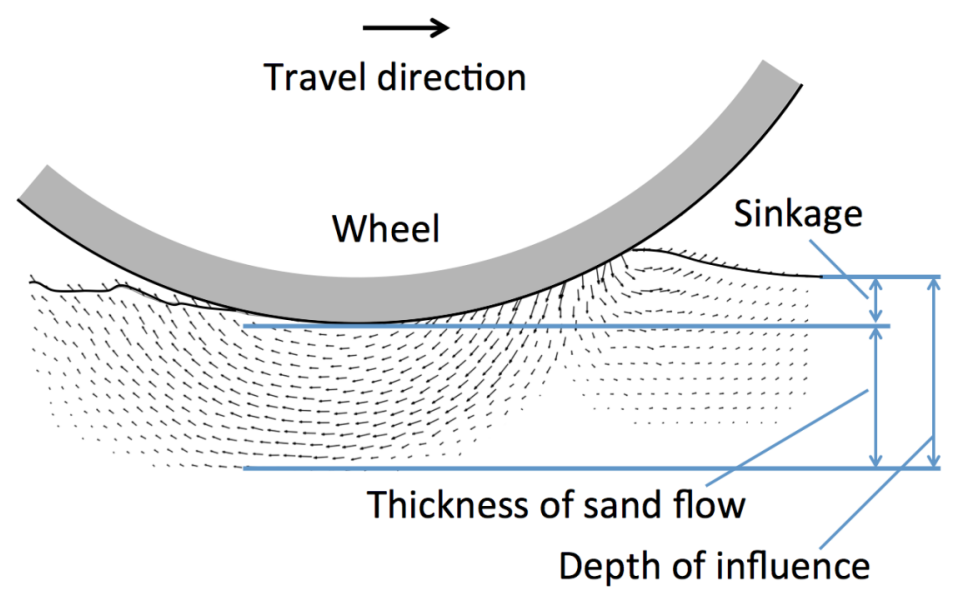

Fig. 7 Definitions of sinkage, the thickness of sand flow and the depth of influence.

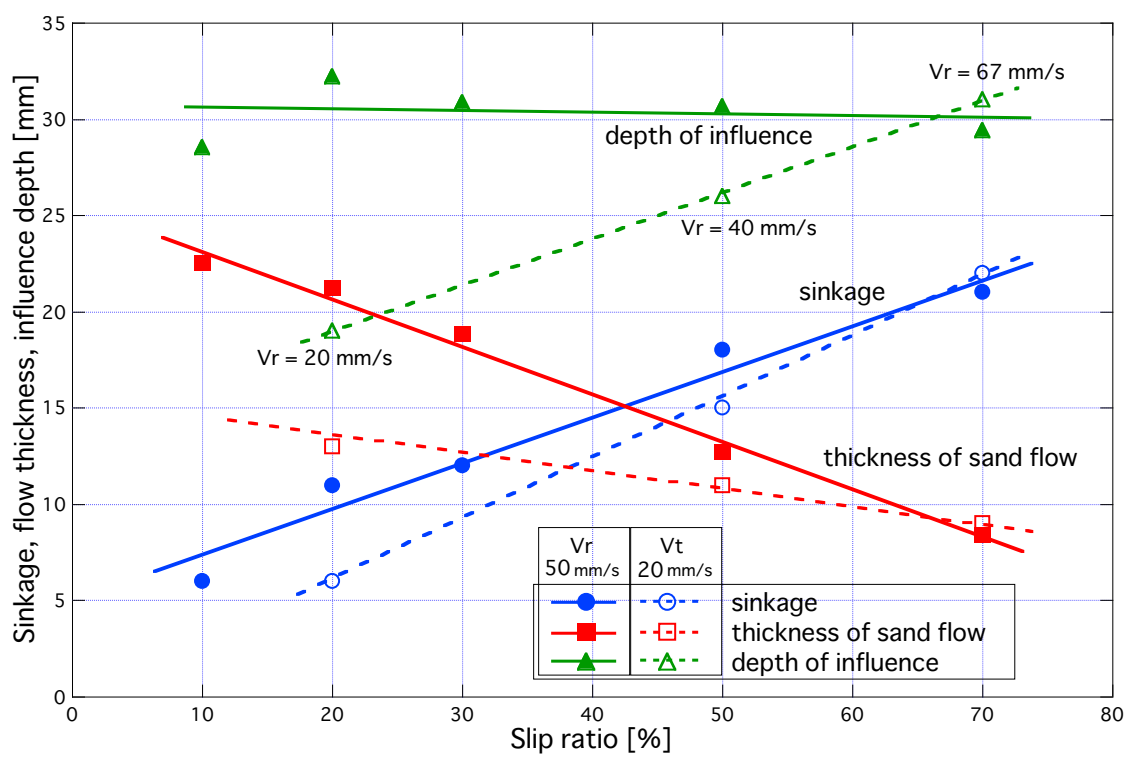

Fig. 8 Wheel sinkage, the thickness of sand flow and the depth of influence for various slip ratios. 


\section{$2 \cdot 4$ 牽引カとトルク}

図 9 は輪荷重ごとの牽引力とすべり率の関係を示したものである. 砂の流動により牽引力には変動が見られる が，ここでは平均值を示している．また，それぞれの実験でも多少のばらつきが見られるため，3ー5 回程度行な った実験における平均值である.ロードセルで測定できる力は車輪を前進させる方向の推進力から砂面より受け る走行抵抗を引いた牽引力であり，これを推進力と走行抵抗に分離して測定することはできない．輪荷重を変化 させた場合, 牽引力は輪荷重が $80 \mathrm{~N}$ まではすべり率とともに増加して飽和寸る. しかし, 接地荷重が大きい場合, 過度に大きい寸べり率で牽引力は減少する．铱引力の負值は走行抵抗が推進力より大きいために車輪の駆動のみ

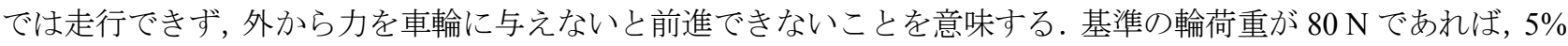
以上の寸心゙り率で自走が可能であり，120 N の輪荷重ではいずれのすべり率でも自走が不可能であることを示し ている. 右図は牽引力を輪荷重で除して無次元化した牽引力係数(Wong, 2001)である. 輪荷重でその值が大きく 異なることが分かる. $80 \mathrm{~N}$ の輪荷重に対しては 5\%程度の牽引力が発生できることになる. 図 10 はすべり率と卜 ルクの関係を示している．すべり率とともにトルクは増加する傾向にあるが，牽引力がす心゙り率の増加で飽和す るにも関わらずトルクが増加するのは，沈下とともに車輪と砂の接触面積が増して走行抵抗が増加するためであ る．右図はトルクを輪荷重と車輪半径で割って無次元化したものであるが，全ての輪荷重ですべり率を通してほ ぼ等しい值となっている，摩擦は押付け力に比例することから，車輪踏面と砂の接触により発生する摩擦に抗す る分がトルクとして発生しているものと考えられる.

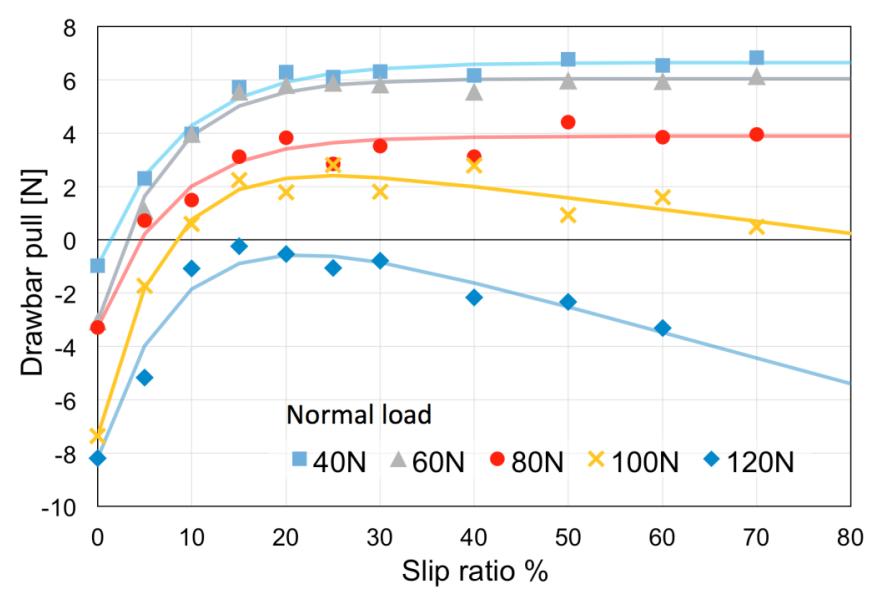

(a) drawbar pull

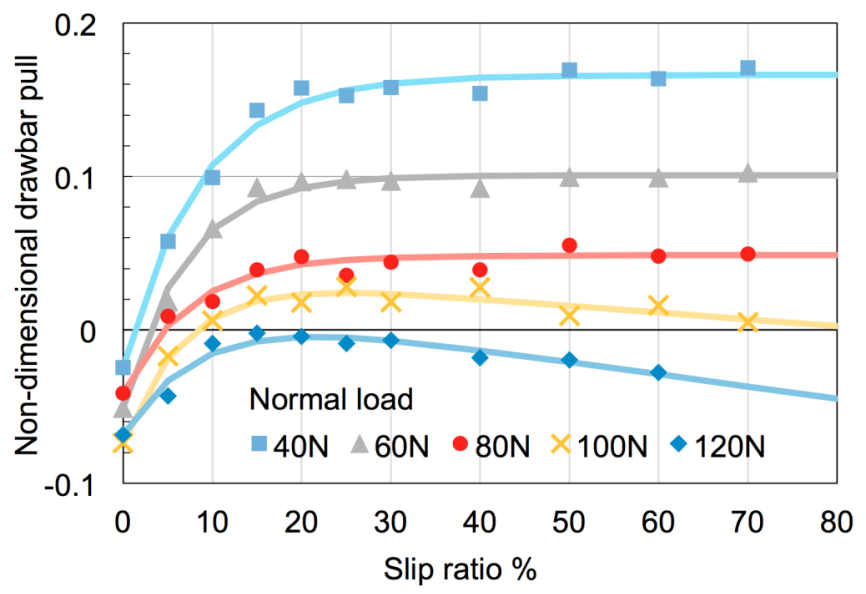

(b) non-dimensional drawbar pull (drawbar pull/normal load)

Fig. 9 Drawbar pull for various normal loads on the wheel $\left(V_{r}=50 \mathrm{~mm} / \mathrm{s}\right)$.
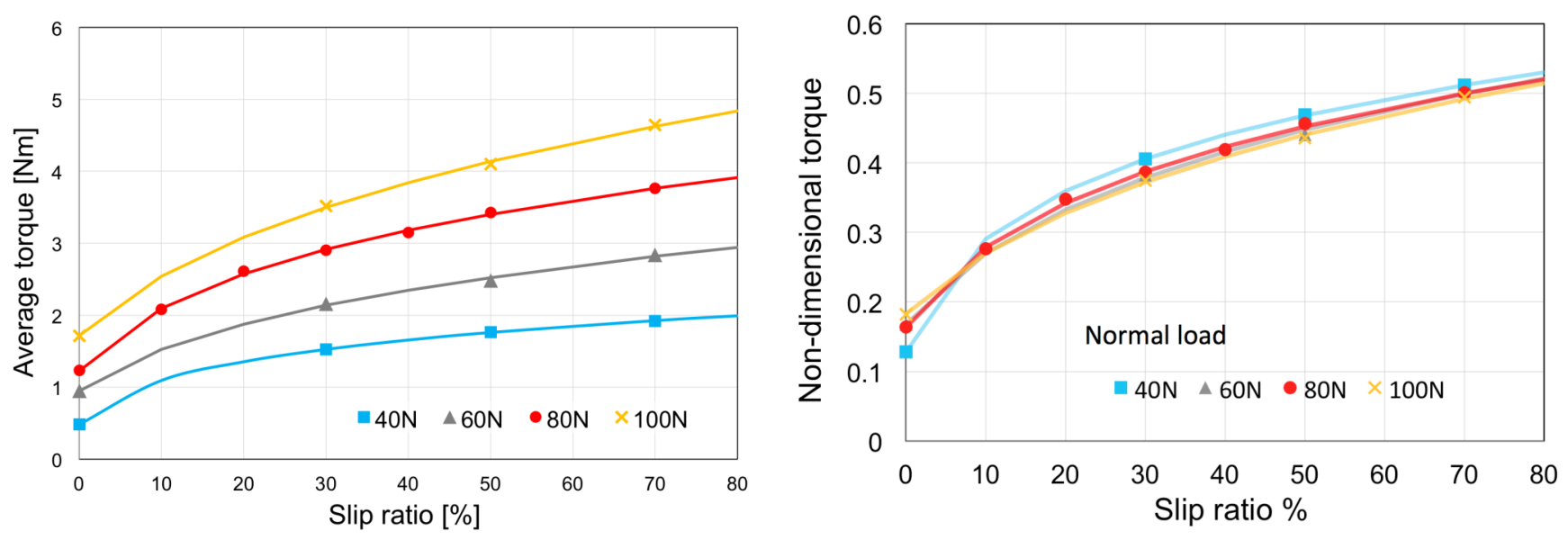

(a) required torque

(b) non-dimensional required torque (torque/normal load/wheel radius)

Fig. 10 Required torque for the wheel rolling under various normal loads $\left(V_{r}=50 \mathrm{~mm} / \mathrm{s}\right)$. 


\section{3. 車輪踏面に作用するカの測定と摩擦モデル}

\section{$3 \cdot 1$ 垂直・剪断力の測定}

車輪踏面の中央に三分力計を埋込み, 砂面との接触状態における垂直力ならびに剪断力を測定した. 図 11 は三 分力計とそれを車輪踏面に埋込んで受感部のみを車輪表面に出した状態を示している. これにより車輪走行時の 車輪中心線上の垂直応力と剪断応力を計測した．図 12 はすべり率 30, 50,70\%における車輪踏面の垂直応力と剪 断応力の分布を示している. 横軸は車輪最下点から回転軸を中心とした角度を示しており, 右が車輪前方となる. 接触開始点からそれぞれの応力は増加しているが，すべり率が大きいほど沈下は大きいために車輪前方の接触開 始角が大きくなる．剪断応力と垂直応力の最大值はすべりが大きい程前方に移動しており，これは一般的な分布 の傾向に一致している(Higa et al., 2015).

\section{$3 \cdot 2$ 踏面の摩擦モデル}

PIV 法では砂粒子の移動速度が分かるため, 踏面付近における車輪と砂の相対速度を明らかできる. 図 13 に示 すように車輪の踏面は移動と回転の合成速度を持つ. 車輪踏面接線方向の速度成分と踏面の近傍にある PIV の測 定点における同方向の速度成分の比較から, 車輪表面付近の砂粒子と車輪踏面との相対速度を求めた. これによ って得られる車輪踏面における相対速度と車輪踏面において測定した剪断応力／垂直応力の関係から摩擦モデル （相対速度と摩擦の関係）を構築する. この摩擦モデルは有限要素法で数值解析を行なうに当たり, 車輪と砂の 接触面で発生する摩擦を計算するモデルとして用いる.

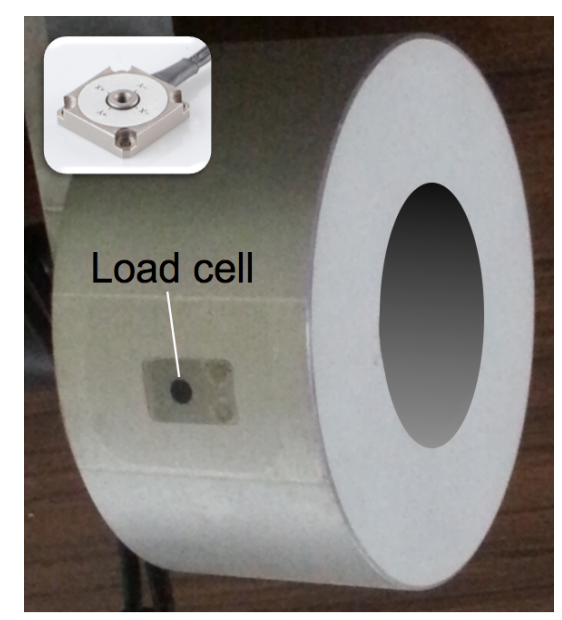

Fig. 11 A triaxial load cell for measuring normal and shear stresses distribution on the wheel tread.

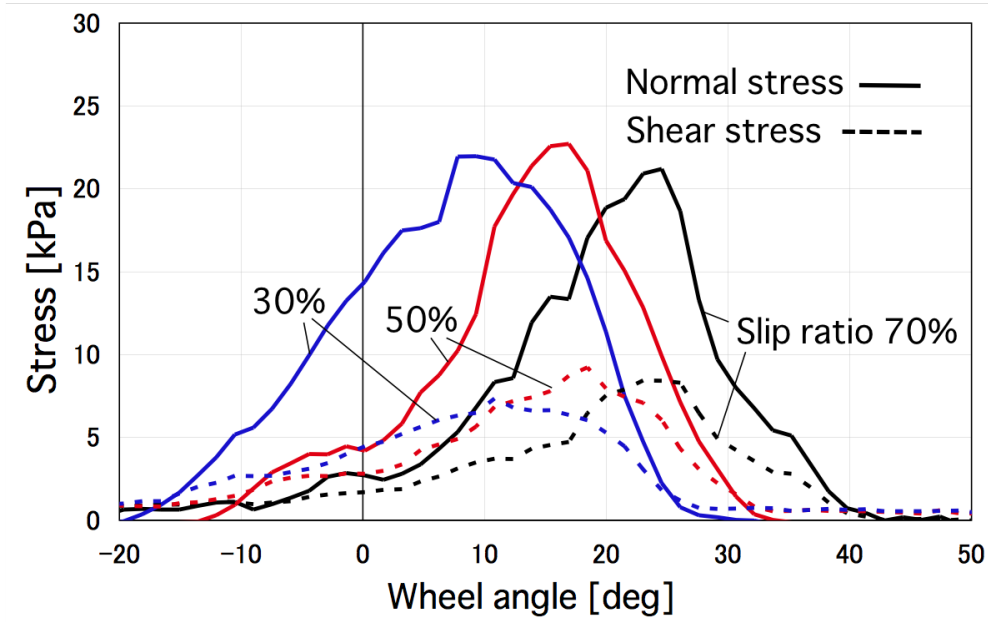

Fig. 12 Distribution of the normal and shear stresses on the wheel tread at slip ratios 30,50 and $70 \%$. 
図 14 は車輪踏面における砂粒子の相対速度と摩擦係数の関係を表したものである.相対速度は車輪周速度で無 次元化して横軸に示している．PIV の速度分布をもとにすべり速度を算出したために，ばらつきが見られるもの の, 相対速度の増加にともない, 摩擦係数が若干増加する傾向が分かる. 相対速度と摩擦係数の関係は有限要素 法で砂と車輪の接触における摩擦の算出に必要となるため, 摩擦係数を次式で与えるものとした.

$$
\mu=a+b s_{t}
$$

$s_{t}$ は踏面の接線方向におけると車輪と砂の相対速度を車輪周速度で無次元化したものである. 式(1)で定義したす べり率は走行における車輪のすべり率であるのに対して， $s_{t}$ は踏面近傍の局所的なすべり率である．式(2)におい て数值解析では $a=0.31, b=0.19$ の值を用いたが，このとき図 14 における実線となる. 軟らかい地面と板の間で は摩擦係数はす心゙り率とともに増加することが知られており(Muro and O’Brien, 2004)，類似性が見られる.

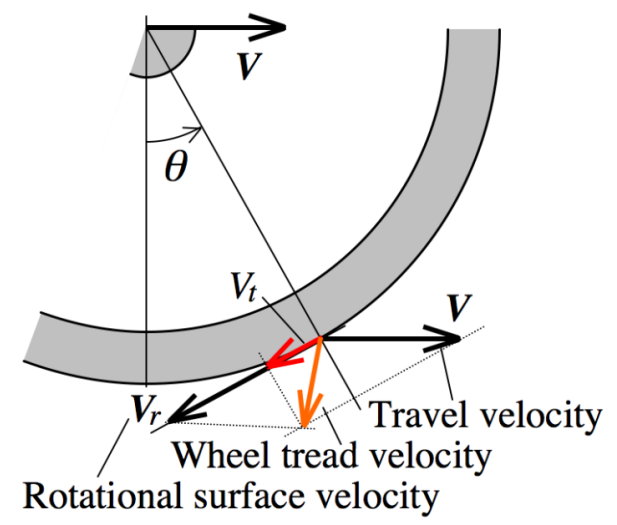

Fig. 13 Velocities of a point on the wheel tread and the tangential velocity.

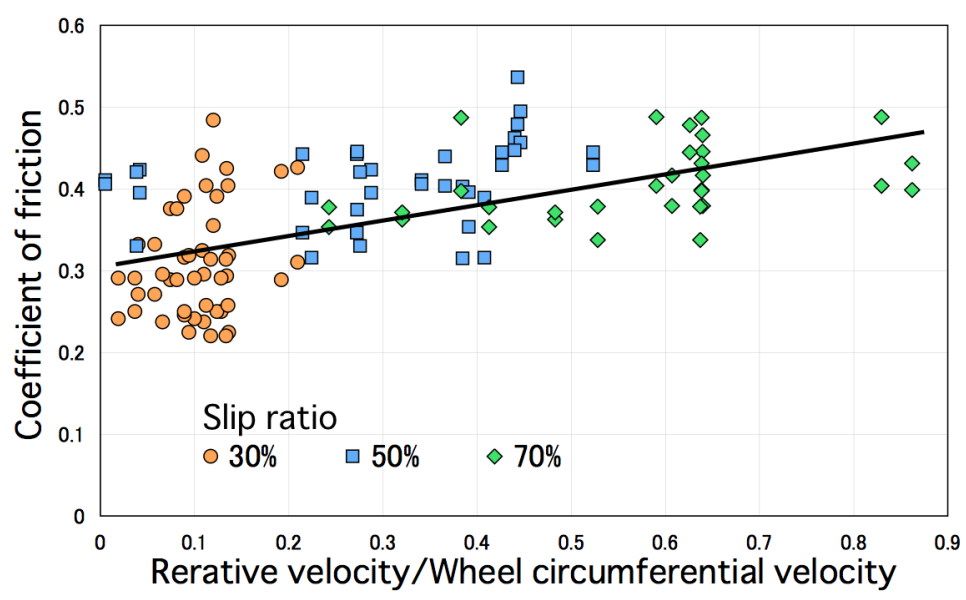

Fig. 14 The relationship between the normalized relative velocities and the coefficients of friction on the wheel tread.

\section{4. 有限要素法による車輪走行の数値解析}

\section{$4 \cdot 1$ 数值解析モデル}

実験と同じ条件において車輪走行の数值解析を有限要素法で行なった. 数值解析には汎用ソフトウェア(Abaqus, 2009)を用いた。輪荷重を $80 \mathrm{~N}$ とし, 車輪が自重で砂面に接地した後に一定のすべり率で車輪に回転速度と移動 速度を与えており, 静止状態から $4 \mathrm{~s}$ で所定の速度に達する. 車輪には自重が作用しており, 前後方向の速度は 指定して与えるものの，上下方向の運動は運動方程式を解いて求まる. このため実験と同様に砂面の反力により 沈下量が定まることになる. 車輪と砂の接触面には前章で述べた摩擦モデルを使用した. 砂の塑性変形に必要な 降伏条件は必要なパラメタの数が少なく簡単に扱える Drucker-Prager モデル(Belytschko et al., 2000)を用いた. これ は，降伏剪断応力が圧力に線形的に依存するモデルあり，降伏条件は次式で表すことができる. 


$$
f=\bar{\sigma}-\alpha I_{1}-Y=0
$$

ここで, $\bar{\sigma}$ は有効 Cauchy 応力, $I_{I}$ は応力の第 1 不変量 (Fung, 1965)であり, 圧力の負值で 3 倍に相当する. また,

$$
\begin{gathered}
\alpha=\frac{2 \sin \phi}{3+\sin \phi} \\
Y=\frac{6 c \cos \phi}{3+\sin \phi}
\end{gathered}
$$

$\phi$ は内部摩擦角, $c$ は粘着力である. 塑性ひずみの進展は降伏曲面に依存しないとする非関連流動則とした.ゆる 詰めの砂の場合，砂粒子間に間隙が存在して圧力により体積の若干の収縮が認められるが，剪断応力による塑性 変形の方が十分に大きいと考えられるために, 塑性状態で体積変化が生じないとして十分な近似が可能である. このため, 塑性ポテンシャル曲面は圧力方向の軸に平行な円筒とし, 塑性ひずみは偏差方向に生じるとした (Belytschko et al., 2000).

主な材料定数については, 体積弾性係数 $K=16.7 \mathrm{MPa}$, 横弾性係数 $G=7.7 \mathrm{MPa}$, 内部摩擦角 $\phi=32^{\circ}$, 粘着力 $c=$ $1.2 \mathrm{kPa}$ とした. 長さ $1000 \mathrm{~mm}$, 深さ $200 \mathrm{~mm}$ で砂の領域を要素で分割し, 有限要素の節点数 14391 , 四角形要素 数 14000 とした. 砂面は車輪と接触する部分を除いて自由表面とし, 砂槽左右壁と底面の砂の境界ではその垂直 方向への変位がないとして境界条件を設定した. なお, 車輪の進行方向と垂直な方向には砂の変位が生じない平 面歪み問題として，実験と同様に二次元での解析を行なった。

車輪は砂面との接触の相互作用で受ける力により上下方向のみの運動を行なう．上下方向の運動は $y$ 軸方向の 次の運動方程式を解くことによって得られる.

$$
m \ddot{y}=-m g+\sum_{i}^{n_{c}} F_{y i}
$$

ここで， $F_{y i}$ は接触する砂面から相互作用によって車輪が受ける有限要素の節点 $i$ における力, $n_{c}$ は車輪と接触す る節点の数である. なお, 数值解析は陽解法であり, Updated Lagrange 法を用いている(Abaqus, 2009).

\section{$4 \cdot 2$ 実験との比較}

図 15 は車輪下の砂の速度分布を実験と数值解析で比較したものである. 車輪周速度 $50 \mathrm{~mm} / \mathrm{s}$ でのすべり速度 $30 \%, 50 \%$ において, 比較的流動が小さい状態と大きい状態をそれぞれ実験と数值解析で比較して示している. 数值解析でも実験と同じように流動の変化が現れており, 定性的に砂質土を走行する車輪に起きる現象を再現し ている.

図 16 はすべり率 $50 \%$ において車輪通過後の砂表面を実験と比較したものである. 数值解析においても実験と 同様の波形が生成される. また，走行開始直後にはおおうなっぶが一つ形成されるが，数值解析でも同様に形成 されるのが分かる. 実験では砂粒子の移動速度は観察できたが, 車輪通過後の砂の内部の変形までは確認が困難 であった. しかし, 数值解析によりひずみを示すことにより, 砂内部に生じる変形を確認することができる. 図 17 は車輪周速度 $50 \mathrm{~mm} / \mathrm{s}$ におけるすべり率 0 - 70\%における計算結果であり, 有効塑性ひずみを色の濃淡で示し ている. すべり率の増加にともない実験と同様に車輪通過後にできる山の数は増加し, 内部の変形が大きくなっ ていることが分かる. 表 2 は波形の山の数を実験と数值解析で比較したものである. すべり率 $70 \%$ の結果では波 数を数えるのが困難であり, 明確に分離していない小さい波形まで数えたものを表中では括弧で示している. 両 者で波の数に差異があり，大きいす心゙り率では数值解析の波数は実験よりも少ない傾向にある. これは，数值解 析で用いた応力歪夕関係のモデルの剪断強度が実際の砂のより高いためであると考えられる.

図 18 は, 沈下量, 流動深さ, 影響深さを実験と数值解析で比較したものである. 数值解析で得られた沈下量は 実験結果と比較して小さく, 流動層が厚く見積もられることが分かる. これも数值解析における構成則モデルが 実際の砂よりも剪断強度が大きいためで, 砂の流動が実際よりも押さえられるためと考えられる. 有限要素法で 
は格子上での変位の近似解を求めるが，格子間の変位が大きすぎると数值計算が破綻するため, 安定した数值計 算が行えるように構成則モデルに小さな值で粘着力を入れており，これが砂の流動を抑制する原因であると言え る. ただ，車輪の沈下量と砂の流動深さを合わせた影響深さは，数值解析と実験で值が異なるもののすべり率に よらずにほぼ一定になっており, 両者ともに同様の傾向を示している.

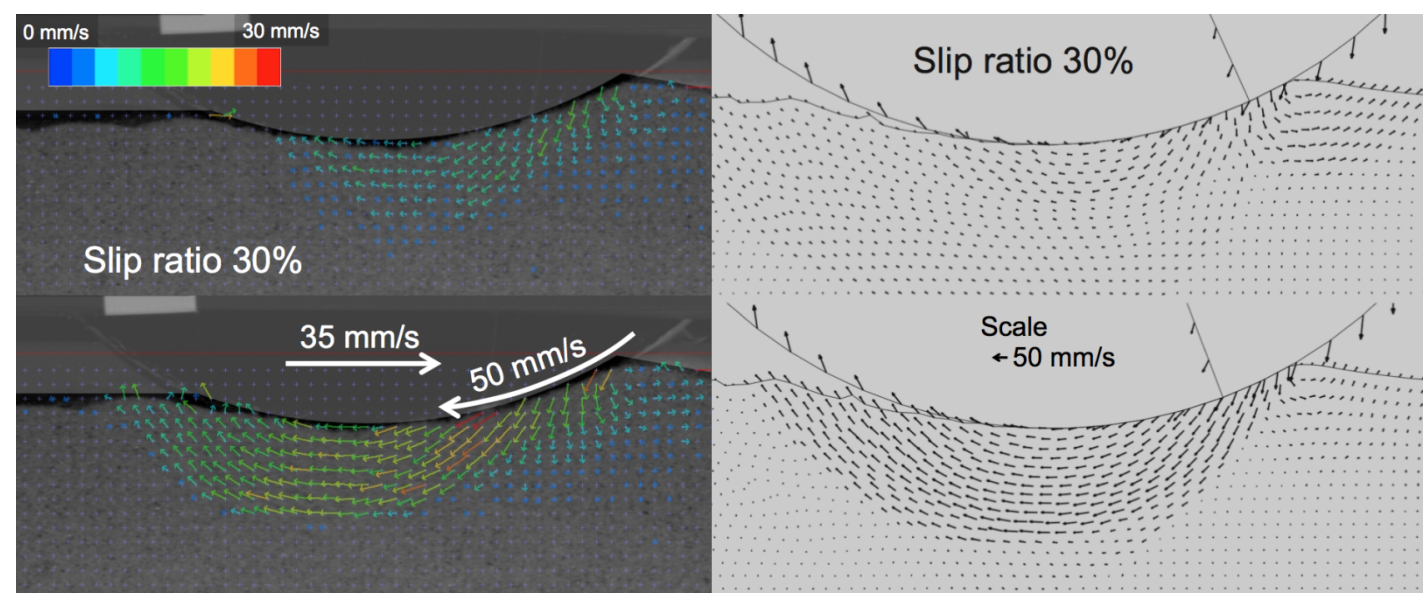

(a) slip ratio $30 \%$

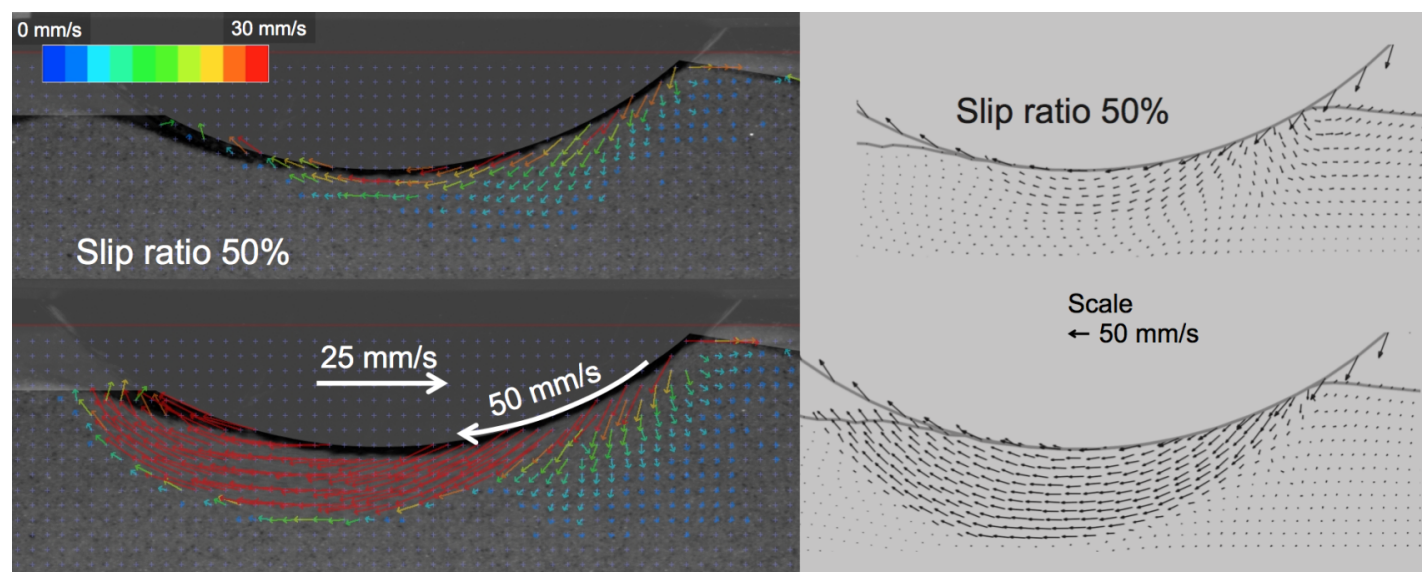

(b) slip ratio $50 \%$

Fig. 15 Comparison of sand particles flow between experiment and simulation, (a) $30 \%$ and (b) $50 \%$ slip ratios.

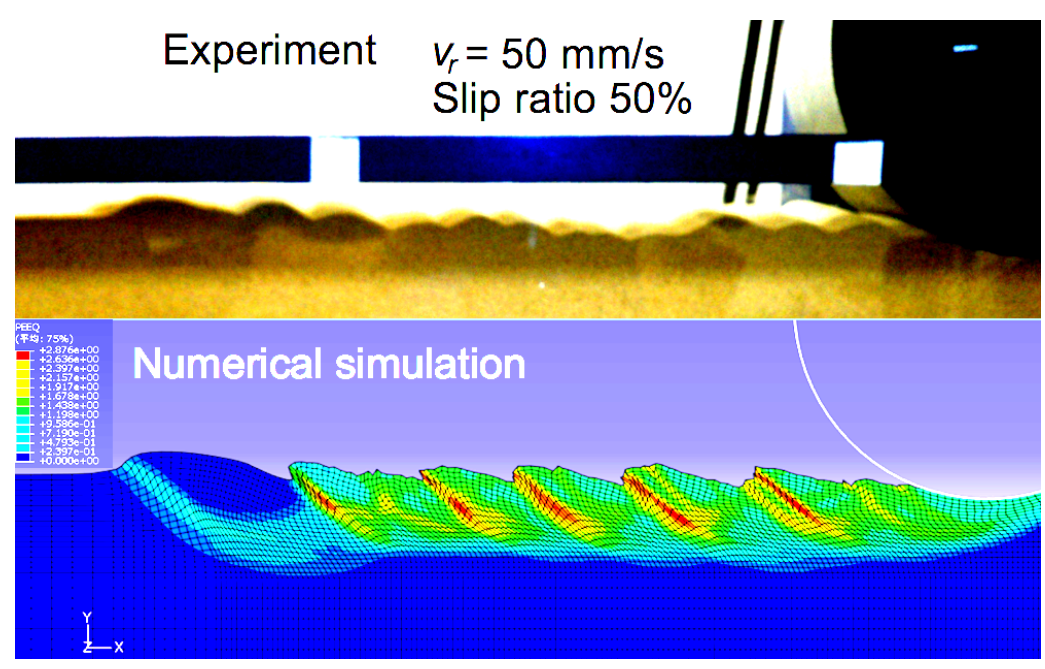

Fig. 16 Comparison of ripple patterns between experiment and simulation at 50\% slip ratio. 


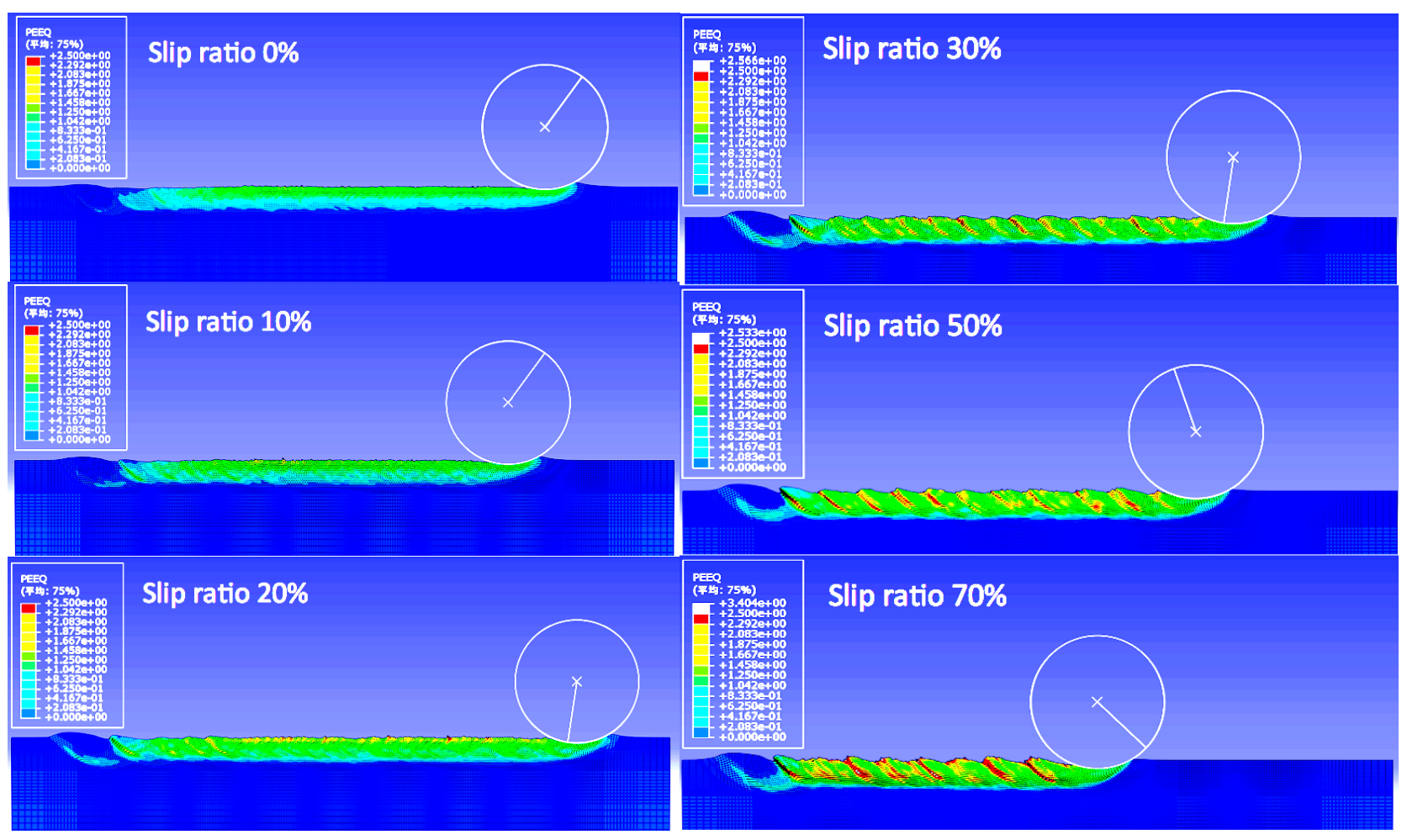

Fig. 17 Wheel travel simulation by the finite element method for slip ratios form 0 to $70 \%$.

Table 2 Comparison of the number of humps for various conditions.

\begin{tabular}{|c|c|c|c|c|}
\hline $\begin{array}{c}\text { Wheel peripheral } \\
\text { velocity [mm/s] }]\end{array}$ & $\begin{array}{c}\text { Slip ratio } \\
{[\%]}\end{array}$ & $\begin{array}{c}\text { Travel velocity } \\
{[\mathrm{mm} / \mathrm{s}]}\end{array}$ & $\begin{array}{c}\text { Experiment } \\
\text { Number of } \\
\text { humps/200 mm }\end{array}$ & $\begin{array}{c}\text { Simulation } \\
\text { Number of } \\
\text { humps/200 mm }\end{array}$ \\
\hline 50 & 20 & 40 & 5 & - \\
\hline 50 & 30 & 35 & 6 & 6 \\
\hline 50 & 50 & 25 & 8 & 7 \\
\hline 50 & 70 & 15 & 13 & $4(7)$ \\
\hline
\end{tabular}

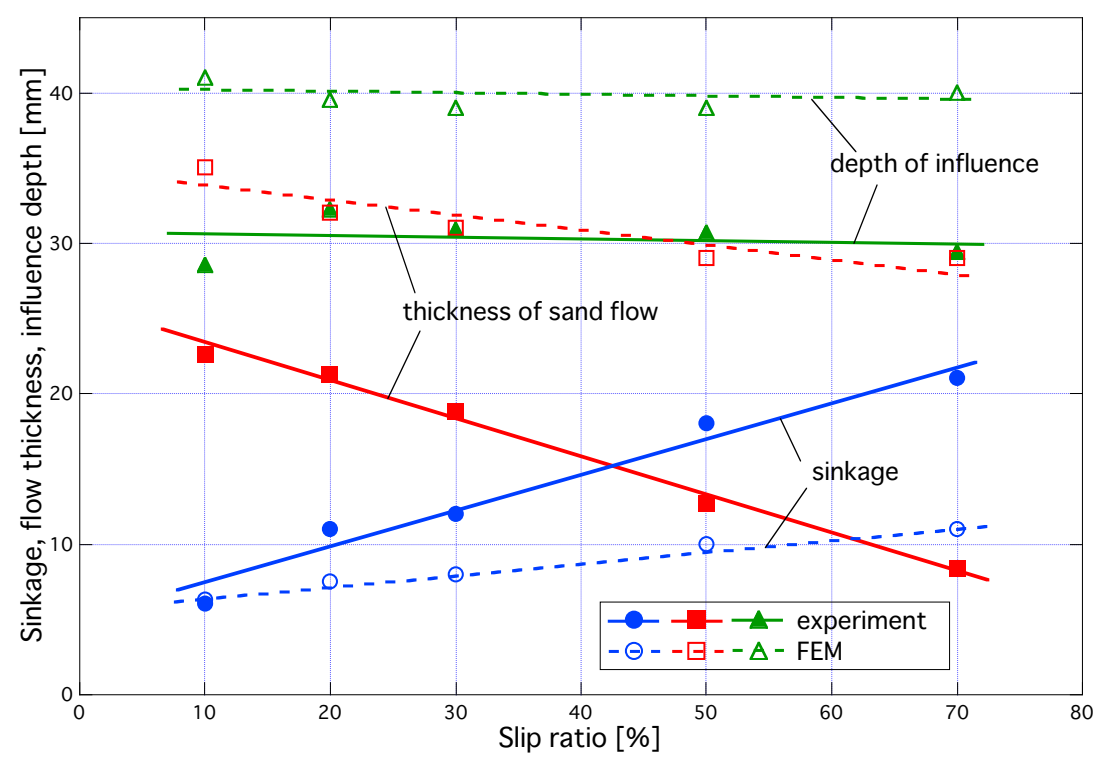

Fig. 18 Comparison of wheel sinkage, the thickness of sand flow and the depth of influence for various slip ratios. 
図 19 は車輪周速度 $50 \mathrm{~mm} / \mathrm{s}$, すべり率 $50 \%$ における牽引力の時間的変化を数值解析と実験で比較したものであ る. $7 \mathrm{~s}$ 以降で両方の牽引力はほぼ近い值となっている. 走行開始直後に铱引力の差が出ているが, 数值解析の剪 断強度が実際の砂よりも大きいことが同様に原因と考えられる. 実験で得られた牽引力の值は土 $2 \mathrm{~N}$ 程度で変動 が見られるが，砂の流動が大きいときに牽引力は大きく両者の変動は一致するが，これは数值解析でも同様に現 われている。

図 20 は, 車輪周速度 $50 \mathrm{~mm} / \mathrm{s}$ で異なるすべり率において安定状態時の牽引力の平均值を実験と数值解析で比較 したものである. 先に示したすべり率 $50 \%$ の条件で数值解析結果は近い值を示しているが，他のすべり率では， 差異が認められる. 特にすべり率 $10 \%$ の牽引力において実験では正值, 数值解析では負值となっており, 数值解 析で車輪が自走できるかどうか判定が正しくできないことになる．車輪の走行性を予測するには車輪に作用する 力は重要な要素であり, より近い值を得ることが求められる. 剪断強度を下げて砂の大きな流動を許容するなど, 数值解析において力学モデルの改善が必要である.

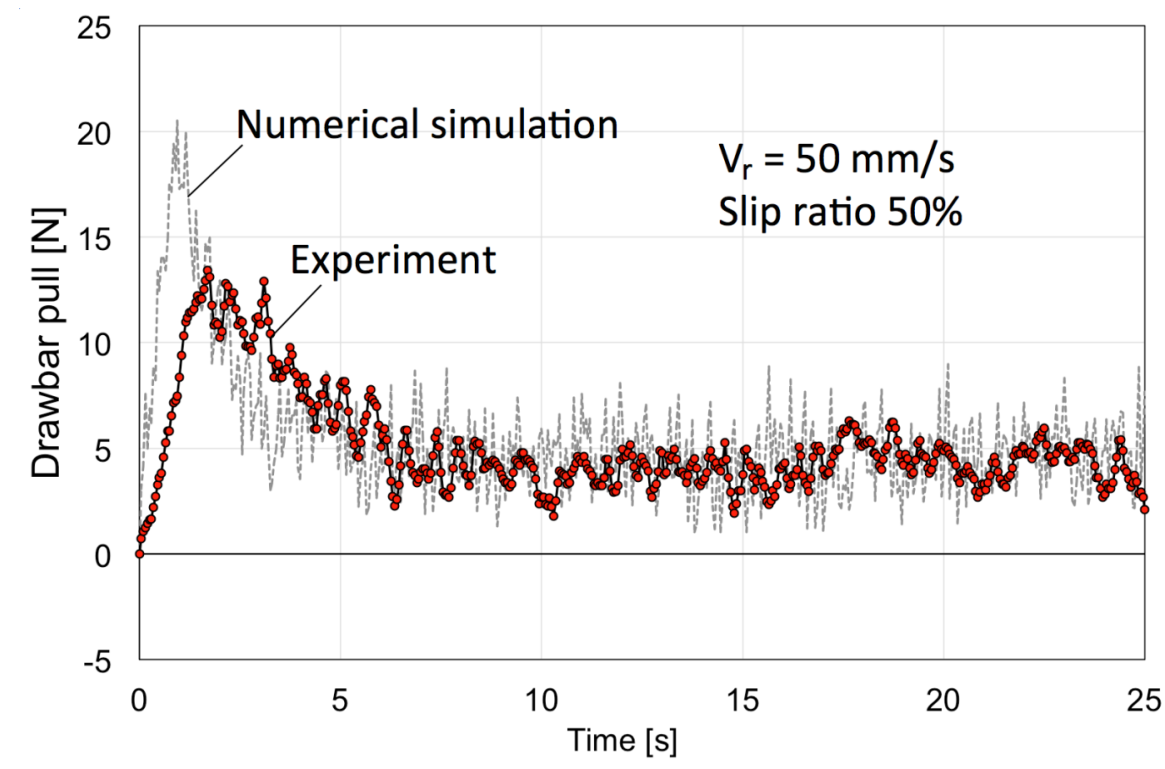

Fig. 19 Comparison of the drawbar pull on the wheel from stationary to steady states.

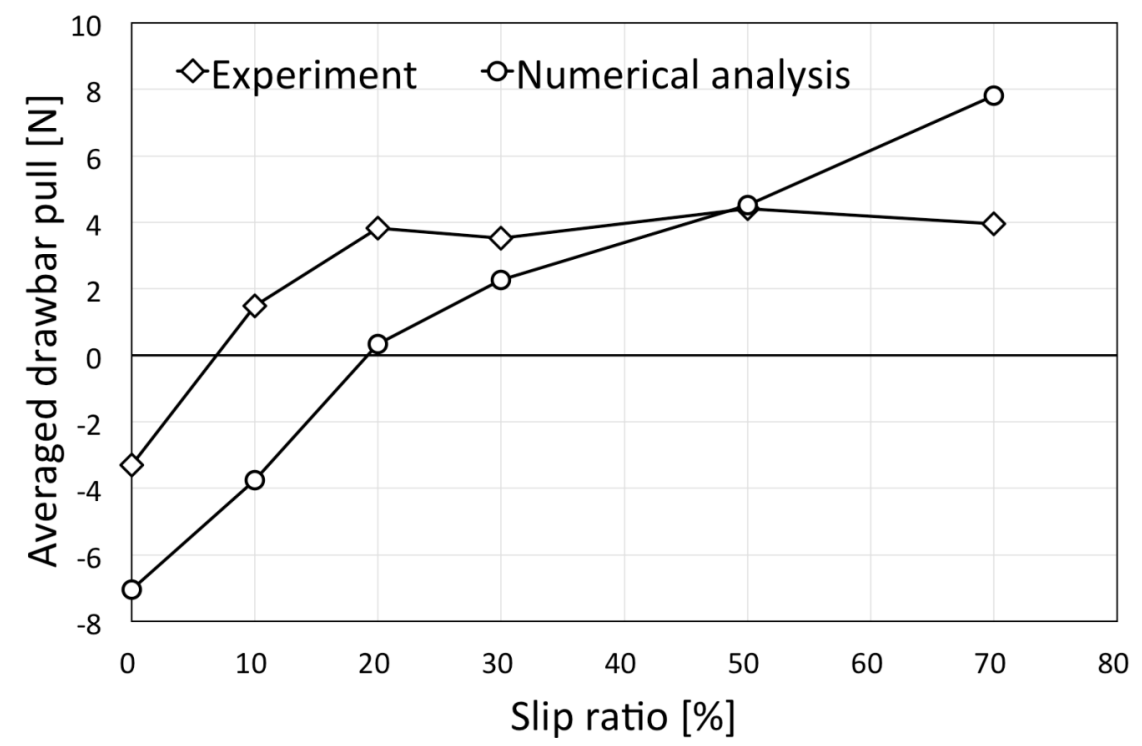

Fig. 20 Comparison of the drawbar pull on the results between the experiment and the numerical simulation. 


\section{5. 結 言}

本研究では, 緩い砂の上で岡性車輪の走行実験を行い, PIV で砂粒子の移動を可視化することで車輪との相互 作用による砂の流動を解析した．また，有限要素法による数值解析により走行実験の再現を行い，その有用性を 検証した。その結果，次のことが明らかとなった.

（1）軟らかい砂を走行する岡性車輪近傍で砂の流動は一様でなく，大小の流動が周期的に発生して車輪通過後 の砂面に波模様を形成する．このとき砂の流動にともない毫引力は変動する．砂と接触する車輪前面の周方向長 さ分が回転するごとにほぼ 1 つの波形が発生した.

(2) 車輪周速度一定の走行においてすべり率の増加で沈下量は増加するものの, 車輪下の砂の流動厚さは減少 した．一方で沈下量に流動厚さを加えた影響深さはすべり率を通してほぼ一定であった.

(3) 有限要素法による数值解析において車輪通過後にできる波形は定性的に再現できた. しかしながら, 走行 予測に重要となる毫引力には乘離が認められた.

(4) 数值計算に用いた構成則モデルならびにパラメタでは剪断強度が実際の砂よりも高く見積もられている. 数值解析においてより大きな砂の流動を許容する手法が必要である.

\section{文献}

Abaqus/CAE User's Manual 6.9, Dassault Systèmes (2009)<http://abaqusdoc.ucalgary.ca/v6.9/>, (参照日 2017 年 4 月 14 日).

Belytschko, T., Liu, W. K. and Moran, B., Nonlinear Finite Elements for Continua and Structures (2000), p.257, John Wiley \& Sons.

内閣府, 平成 28 年版 防災白書 (2016), p.附-37

Chhaniyara, S., Brunskill, C., Yeomans, B., Matthews, M.C., Saaj, C., Ransom, S. and Richter, L., Terrain trafficability analysis and soil mechanical property identification for planetary rovers: A survey, Journal of Terramechanics, Vol.49 (2012), pp. 115-128.

Fung, Y. C., Foundations of Solid Mechanics (1965), pp.73-74, Prentice Hall.

HAKUTO, <https://team-hakuto.jp/>, (参照日 2017 年 4 月 14 日).

Higa, S., Nagaoka, K., Nagatani, K. and Yoshida, K., Measurement and modeling for two-dimensional normal stress distribution of wheel on loose soil, Journal of Terramechanics, Vol.62 (2015), pp.63-73.

細野康代, 吉嶺充俊, 豊浦砂の粒度分布, 土木学会第 64 回年次学術講演会 (2009), pp.335-336.

JAXA，小型月着陸実証機 (SLIM) プロジェクト移行審查の結果について(2016) $<$ http://www.jaxa.jp/press/2016/07/files/20160714_slim_01_j.pdf>, (参照日 2017 年 4 月 14 日).

Muro, T. and O'Brien, J., Terramechanics: Land Locomotion Mechanics (2004), CRC Press.

Ozaki, S., Hinata, K., Senatore, C. and Iagnemma, K., Finite element analysis of periodic ripple formation under rigid wheels. journal of Terramechanics, Vo.61 (2015), pp.11-22.

Senatore, C., Wulfmeier, M., Vlahinic, I., Andrade, J. and Iagnemma, K., Design and implementation of a particle of image velocimetry method for analysis of running gear-soil interaction, Journal of Terramechanics, Vol.50 (2013), pp.311-326.

Shikanai, T., Hashiguchi, K., Nohse, Y., Ueno, M. and Okayasu, T., Precise measurement of soil deformation and fluctuation in drawbar pull for steel and rubber-coated rigid wheels, Journal of Terramechanics, Vol.37 (2000), pp.21-39.

Taheri, Sh., Sandu, C., Taheri, S., Pinto, E. and Gorsich, D., A technical survey on terramechanics models for tire-terrain interaction used in modeling and simulation of wheeled vehicles, Journal of Terramechanics, Vol. 57 (2015), pp.1-22.

Timoshenko, S. P. and Goodier, J. N., Theory of Elasticity, $3^{\text {rd }}$ ed. (1987), pp.15-17, McGraw-Hill.

Tiwari, V. K., Pandey, K. P. and Pranav, P. K., A review on traction prediction equations, Journal of Terramechanics, Vol.47 (2010), pp.191-199.

Wong, J.Y., On the study of wheel-soil interaction, Journal of Terramechanics, Vol.21, No.2 (1984), pp.117-131.

Wong, J.Y., Theory of Ground Vehicles, $3^{\text {rd }}$ ed. (2001), pp.126-128, Willey-Interscience. 


\section{References}

Abaqus/CAE User's Manual 6.9, Dassault Systèmes (2009), available from <http://abaqusdoc.ucalgary.ca/v6.9/>, (accessed on 14 April, 2017).

Belytschko, T., Liu, W. K. and Moran, B., Nonlinear Finite Elements for Continua and Structures (2000), p.257, John Wiley \& Sons.

Cabinet Office Japan, White paper on Disaster Management (2016), p.A-37(in Japanese).

Chhaniyara, S., Brunskill, C., Yeomans, B., Matthews, M.C., Saaj, C., Ransom, S. and Richter, L., Terrain trafficability analysis and soil mechanical property identification for planetary rovers: A survey, Journal of Terramechanics, Vol.49 (2012), pp. 115-128.

Fung, Y. C., Foundations of Solid Mechanics (1965), pp.73-74, Prentice Hall.

HAKUTO, available from <https://team-hakuto.jp/>, (accessed on 14 April, 2017) (in Japanese).

Higa, S., Nagaoka, K., Nagatani, K. and Yoshida, K., Measurement and modeling for two-dimensional normal stress distribution of wheel on loose soil, Journal of Terramechanics, Vol.62 (2015), pp.63-73.

Hosono, Y. and Yoshimine, M., Toyoura-suna no ryudo-bunpu, $64^{\text {th }}$ Japan Society of Civil Engineers Annual Meeting (in Japanese) (2009), pp.335-336.

JAXA, Kogata tsuki-chakuriku jisshouki, Smart Lander for Investigating Moon (SLIM) project (2016), available from $<$ http://www.jaxa.jp/press/2016/07/files/20160714_slim_01_j.pdf>, (accessed on 14 April, 2017) (in Japanese).

Muro, T. and O'Brien, J., Terramechanics: Land Locomotion Mechanics (2004), CRC Press.

Ozaki, S., Hinata, K., Senatore, C. and Iagnemma, K., Finite element analysis of periodic ripple formation under rigid wheels. journal of Terramechanics, Vo.61 (2015), pp.11-22.

Senatore, C., Wulfmeier, M., Vlahinic, I., Andrade, J. and Iagnemma, K., Design and implementation of a particle of image velocimetry method for analysis of running gear-soil interaction, Journal of Terramechanics, Vol.50 (2013), pp.311-326.

Shikanai, T., Hashiguchi, K., Nohse, Y., Ueno, M. and Okayasu, T., Precise measurement of soil deformation and fluctuation in drawbar pull for steel and rubber-coated rigid wheels, Journal of Terramechanics, Vol.37 (2000), pp.21-39.

Taheri, Sh., Sandu, C., Taheri, S., Pinto, E. and Gorsich, D., A technical survey on terramechanics models for tire-terrain interaction used in modeling and simulation of wheeled vehicles, Journal of Terramechanics, Vol. 57 (2015), pp.1-22.

Timoshenko, S. P. and Goodier, J. N., Theory of Elasticity, $3^{\text {rd }}$ ed. (1987), pp.15-17, McGraw-Hill.

Tiwari, V. K., Pandey, K. P. and Pranav, P. K., A review on traction prediction equations, Journal of Terramechanics, Vol.47 (2010), pp.191-199.

Wong, J.Y., On the study of wheel-soil interaction, Journal of Terramechanics, Vol.21, No.2 (1984), pp.117-131.

Wong, J.Y., Theory of Ground Vehicles, $3^{\text {rd }}$ ed. (2001), pp.126-128, Willey-Interscience. 